\title{
Plano Amazônia Sustentável: uma nova concepção estatal de desenvolvimento para a Amazônia?
}

Selecina Henrique Locatelli

Curso: Mestrado em Sociologia

Data da defesa: 28 de agosto de 2009

Orientador: Prof. Dr. Marcelo Carvalho Rosa

\section{Resumo}

Para analisar a concepção de desenvolvimento da região amazônica, são abordadas as diferentes denominações que a Amazônia recebeu nos últimos 50 anos, com o objetivo de compreender como esta tem sido construída. Em seguida, deu-se ênfase a alguns planos de desenvolvimento, a saber: "Plano de Valorização da Amazônia", "Plano de Integração Nacional", "Brasil em Ação" e "Avança Brasil” e ao Plano Amazônia Sustentável (PAS) - concepção atual de desenvolvimento, estabelecendo-se um confronto entre as diversas concepções de desenvolvimento neles identificadas.

A Sociologia nos mostra que as várias concepções de Amazônia estão ancoradas na concepção sociológica e política de desenvolvimento, ou seja, cada denominação atribuída à região corresponde a um determinado tipo de intervenção do Estado. Embora o PAS tenha propagado a adoção da concepção de desenvolvimento sustentável para a Amazônia, os Planos Plurianuais (PPAs) 20042007 e 2008-2009 não apresentaram os meios de financiá-lo. Deste modo, formalmente, o Programa de Aceleração do Crescimento (PAC) tornou-se o programa de desenvolvimento do Brasil e da 
Amazônia, priorizando os investimentos públicos nas áreas de infraestrutura física e um grupo de medidas de incentivo ao investimento privado por meio da divisão do País em duas frações.

Tais constatações reforçam a hipótese de que o atual governo não fez rupturas drásticas com o modo de pensar o desenvolvimento da Amazônia iniciado formalmente há pouco mais de meio século: o modelo desenvolvimentista industrial apenas foi adaptado à abordagem discursiva sustentável. O PAS nasceu com objetivos audaciosos de incluir a variável da transversalidade ambiental na ação política, enfrentar a grilagem de terras e a violação dos direitos humanos, mas, até agora, o Estado brasileiro, carecedor de legitimidade, não conseguiu retirá-lo da categoria teórica de instrumental metodológico de interação entre os níveis de governo federal e estadual, e as consultas/audiências públicas.

Palavras- chave: Amazônia; desenvolvimento sustentável; Estado. 